\title{
Regression equations for estimating tree volume and biomass of important timber species in Meghalaya, India
}

\author{
Krishna Giri ${ }^{1, *}$, Rajiv Pandey $^{2}$, R. S. C. Jayaraj ${ }^{1}$, R. Nainamalai ${ }^{3}$ and \\ Subhash Ashutosh ${ }^{3}$
}

${ }^{1}$ Rain Forest Research Institute, Jorhat 785 001, India

${ }^{2}$ Forest Research Institute, Dehradun 248 001, India

${ }^{3}$ Forest and Environment Department, Government of Meghalaya, Shillong 793 001, India

\begin{abstract}
Linear regression models were developed for four ecologically and economically important tree species of Meghalaya, India, viz. Betula alnoides, Duabanga grandiflora, Magnolia champaca and Toona ciliata. In the present study a non-destructive approach has been used for measurement of required variables, i.e. diameter at breast height (DBH), basal diameter, tree height, end-diameters and length of frustum. Comparison of various models of relationship on the basis of adj. $R^{2}$ values showed that the value for linear function $\left(V=f\left(d^{2} h\right)\right)$ was more than 0.90 for all the four tree species, except lowest diameter class of $T$. ciliata (10-30 cm diameter class). Hence this linear regression equation was selected for development of diameter class-wise volume equations. Volume of the stem was taken as the dependent variable, while DBH and tree height were used as independent variables, transformed in the form of $d^{2} h$ to develop regression equation. Similarly, linear regression equations for each tree species were also developed using linear function $\left[\left(V=f\left(d^{2}\right)\right)\right]$, considering tree volume as an dependent variable and $D B H$ as an independent variable, transformed in the form of $V=d^{2}$. The present study is among a few attempts to develop regression models without the felling of trees since 1977 and an initial attempt using advanced measurement equipment in North East (NE) India, under the current regime of ban on tree felling. The regression equations developed in this study can be used for estimation of timber yield and carbon content of the selected tree species found in the Meghalaya forests.
\end{abstract}

Keywords: Biomass, regression equations, tree volume, timber species.

THE ultimate objective of forest mensuration is to estimate the quantity of timber contained in the forests. The volume of trees is calculated either after felling them or in the standing crop. For volume estimation of standing trees, mathematical models developed through multiple

\footnotetext{
*For correspondence. (e-mail: krishna.goswami87@gmail.com)
}

regression analyses are found most convenient as felling of trees is avoided. Modelling has been used in forestry from mid-1880s, when the Central European foresters were using graphical methods of modelling the growth and yield of forests. These models continued to be used in other places as well, until the development of mechanical calculators in combination with new statistical analysis methods. These new statistical tools and techniques enabled preparation of yield and volume tables more efficiently $^{1}$. Stiellfor ${ }^{2}$ and Woessner ${ }^{3}$ proposed regression equations for volume/biomass prediction of different parts of trees like bole, roots and branches. Harding and Griger ${ }^{4}$ developed allometric models $Y=a d^{\mathrm{b}}$ and $Y=a d^{\mathrm{b}} h^{\mathrm{c}}$, where $Y$ is the mass, $d$ the diameter at breast height (DBH), $h$ the height and $a, b, c$ are mathematical constants.

The yield and volume of timber are required by the forest managers based on tree diameter, height, basal area, form, bark thickness, etc. ${ }^{5,6}$, and the relationships between these parameters serve as a key to tree volume estimation. Regression models have been most widely used for estimating tree volume. A good model should provide information that is sufficiently precise and comprehensive to execute the intended purpose in a simple manner, be easily understood and also helpful for drawing inferences; and regression models have served these purposes.

Allometric models relate $\mathrm{DBH}$ to other components and provide relatively precise estimates of volume and biomass ${ }^{7}$. These models vary widely, but the commonly used method is linear model $(Y=a+b x)$, where $Y$ is the biomass, $a$ and $b$ are slope and intercept respectively and $x$ is the $\mathrm{DBH}^{8}$. The precise estimation of tree volume and biomass in forest ecosystems is essential for commercial timber extraction and above-ground biomass (AGB) carbon stock assessment. Assessment of carbon sequestration potential in terrestrial ecosystems using regression models is a commonly used approach ${ }^{9-11}$. Several regression models have been developed to estimate biomass or carbon stock for forestry species ${ }^{10,12}$, which are being used to prepare volume tables ${ }^{13}$ and to estimate carbon in different forest types ${ }^{14}$. The total biomass obtained from such models is further converted into carbon content by 


\section{RESEARCH ARTICLES}

multiplying with 0.5 , considering that tree biomass contains $50 \%$ carbon $^{15}$.

In several other studies tree height, $\mathrm{DBH}$ and wood density have been used as independent variables for estimating $\mathrm{AGB}$, and the relationship between $\mathrm{AGB}$ and $\mathrm{DBH}$ have been found to be the best fit for tree biomass estimation $^{9,10}$. Since trees constitute the major pool of biomass carbon, many studies on forest carbon budget have focused only on tree AGB estimation ${ }^{16}$. According to the United Nations Framework Convention on Climate Change (UNFCCC), the signatory nations have to report the state of forest resources and temporal as well as spatial, fine-gained carbon stock inventories ${ }^{17,18}$. Harvesting of trees and weighing their parts is the most accurate way of biomass and carbon stock estimation, but due to ban on green felling in India this approach is often used to validate the estimates of carbon stock using nondestructive in situ measurements and remote sensing ${ }^{19,20}$. For instance, Joshi et al. ${ }^{21}$ developed allometric equations for Paulownia tomentosa to estimate biomass and carbon stock using harvest method.

At present more emphasis is being given to the non-destructive methods of biomass and carbon stock estimation because they are less time-consuming and cost-effective than the harvest method. Species-specific, regional and local volume equations give more accurate estimates of forest biomass and carbon as well as the merchantable timber wealth of a particular forest area. The present study was undertaken with the objective to develop volume equations for selected tree species of Meghalaya, NE India. These species were selected keeping in view their economical and ecological importance for the state, as reported by the Forest and Environment Department, Government of Meghalaya and nonavailability of volume table for the species.

\section{Materials and methods}

(1) Hand-held GPS, Garmin-make, model-eTrex 10: Used for recording geo-coordinates of the survey and sampling sites in the field.

(2) Nikon Laser 550A Range Finder ${ }^{22}$ : Used for measurement of total tree height, height at the occurrence of the first branch of each individual tree and length of frustum.

(3) Mantax Black Calliper with Gator Eyes, make: Haglof Sweden ${ }^{23}$ : Used for measurement of diameter from a distance with laser beam (diameter measurement at different heights for each tree).

\section{Study site}

Meghalaya is situated between $25^{\circ} 47^{\prime}-26^{\circ} 10^{\prime} \mathrm{N}$ and $89^{\circ} 45^{\prime}-92^{\circ} 45^{\prime} \mathrm{E}$ covering an area of $22,720 \mathrm{sq}$. $\mathrm{km}$. Out of $15,657 \mathrm{sq} . \mathrm{km}$ forest area in the state, $1027.20 \mathrm{sq} . \mathrm{km}$ is under the control of State Forest Department and the remaining area is either private or clan/communityowned and is under the control and management of Autonomous District Councils.

\section{Field surveys and data collection}

Extensive surveys were carried out in the entire state for measurement of tree parameters such as basal diameter, $\mathrm{DBH}$, total tree height, lower end, middle and upper end diameter and length of frustum. The focus of the survey was healthy trees, while those with deformities in tree architecture were not considered in the population; therefore, none of the diseased, deformed and abnormal trees were accounted for sampling and measurement of the desired variables. In case of two large boles from a single tree, measurement of both the boles was considered and recorded for further processing. The standing trees of each species were hypothetically marked into smaller $\operatorname{logs}$ and the desired measurements were taken without the felling of trees. Depending on the height of merchantable bole, length of frustum (logs) was kept 3-4 m for each tree to measure at least 4-5 sections, and repeated measurements were taken till constant values were obtained. Due to ban on tree felling in the forests, volume of trees could not be measured through destructive sampling.

\section{Statistical analysis}

For the present study, data were collected on the four tree species (viz. Betula alnoides, Duabanga grandiflora, Magnolia champaca and Toona ciliata) by measuring parameters, viz. basal diameter, DBH, height at the occurrence of the first branch, tree height, diameter at the top end, lower end and middle of the frustum and its length. All the trees were divided into three diameter classes according to their DBH, viz. 10-30, 31-50 and $>50 \mathrm{~cm}$. The collected data were used to develop the volume equations.

For this, first the volume of each tree was calculated, for which, the volume of all the logs, sectioned by imagination, was calculated and summed up. The volume of frustum of each tree was calculated using Newton's formula ${ }^{24}$ for estimating individual tree stem volume as

$$
V=\frac{1}{6}\left(A_{1}+4 A_{\mathrm{m}}+A_{\mathrm{u}}\right) * l
$$

where $A_{1}$ is the lower end area, $A_{\mathrm{m}}$ the middle portion area and $A_{\mathrm{u}}$ is the upper end area of the frustum and $l$ is the length of the frustum.

This volume equation may also be expressed as

$$
V=\frac{\pi}{24}\left(d_{1}^{2}+4 d_{\mathrm{m}}^{2}+d_{\mathrm{u}}^{2}\right) * l
$$

where $d_{1}$ is at lower end diameter, $d_{\mathrm{m}}$ the middle portion diameter, $d_{\mathrm{u}}$ the upper end diameter of the frustum and $l$ is the frustum length. 
The above formula was chosen depending on the requirements and the dataset collected for establishment of volume prediction models. None of the trees having physical deformities was considered for sampling even not found in our sample plots. The growth of all tree species was uniform in the forest. These conditions facilitated opting the formula, moreover, the literature also supports use of the formula for estimating log volume and total volume of the trees ${ }^{25,26}$.

$\mathrm{DBH}$ and diameter of frustum were recorded in centimetres, however, length of the frustum and total tree height were measured in metres. Therefore, all the parameters were converted into metres, and volume was calculated in cubic metres.

Regression analysis is a quantitative method applied to find out the relationship between a dependent variable and one or more independent variables. It specifies the relation of dependent variable $(Y)$ to a functional combination of independent variables $(X)$ and unknown parameter $(\beta)$, which can be expressed as

$$
Y=f(X, \beta) .
$$

Volume of the stem was taken as the dependent variable, and $\mathrm{DBH}$ and tree height were taken as independent variables, transformed in the form of $d^{2} h$ to develop regression equation. Also, the model was of the form where the constant term was ignored as it would predict the volume of the tree in spite of the fact that diameter and tree height are zero. Hence the constant term does not have any significance. Minimum of 25 trees in each diameter class were taken for regression analysis. Diameter class-wise stem volume and biomass equations for selected tree species were also developed using linear model $\left[V=f\left(d^{2}\right)\right]$, where stem volume was taken as the dependent variable and $\mathrm{DBH}$ as the independent variable, transformed in the form of $V=d^{2}$.

Regression models were developed using SPSS V16.0 software $^{27}$. Initially, a number of models of different forms were run on the data in order to select the one which would give the best fit. Comparison was made on the basis of the adjusted adj. $R^{2}$ values obtained for different models. The adj. $R^{2}$ of linear function $\left(V=f\left(d^{2} h\right)\right)$ was more than 0.900 for all the four tree species. Hence the linear regression model was selected.

\section{Results and discussion}

Surveys were carried out in the entire state for data collection of each tree species, covering 18 locations in Garo Hills, Khasi Hills, Jaintia Hills and Ri-Bhoi districts. Geo-coordinates of all the sampling locations were reordered and a sampling location map was prepared (Figure 1). Volume equations for each diameter class (10-30, 3150 and $>50 \mathrm{~cm} \mathrm{DBH}$ ) of $B$. alnoides were developed using linear regression analysis (Table 1). The regression models having $0.93,0.92$ and $0.92 R^{2}$ values for $10-30$, $31-50$ and $>50 \mathrm{~cm}$ diameter class respectively, were found to fit best and used for preparation of regional volume tables. These regression models can be used for estimation of merchantable timber in the forests. The equations can also be used for estimation of biomass using wood specific gravity of the species and converted into carbon content using 0.5 multiplication factor.

Similarly, regression models for three diameter classes (10-30, 31-50 and $>50 \mathrm{~cm} \mathrm{DBH)} \mathrm{of} \mathrm{D.} \mathrm{grandiflora} \mathrm{were}$ also developed. The values of adj. $R^{2}$ for each diameter class were $0.95,0.91$ and 0.91 respectively (Table 2 ). The biomass and carbon content of $D$. grandiflora can be estimated using the biomass equation given in Table 2. The volume models are useful for the preparation of volume tables as well as estimation of merchantable timber in the entire state. Diameter class-wise regression models were also developed for M. champaca for Meghalaya. Several models were run to find out the best-fit equations for each diameter class, and the equations having values of $0.93,0.92$ and 0.98 adj. $R^{2}$ for $10-30,31-50$ and $>50 \mathrm{~cm}$ diameter class respectively, were found to fit best (Table 3). The merchantable volume, biomass and carbon content of standing trees can be estimated using these regression equations without felling of trees (Table 3 ). Statistical analysis of the data collected for development of tree volume models for $T$. ciliata revealed that the maximum coefficient of determination for diameter class $10-30 \mathrm{~cm}$ was 0.88 . Hence this model was considered to be the best fit for stem volume, biomass and carbon estimation in the standing trees. Values of $R^{2}$ for $31-50$ and $>50 \mathrm{~cm}$ diameter class were 0.93 and 0.94 respectively (Table 4).

Unlike the linear regression equations developed considering volume as a dependent variable and DBH as well as tree height as independent variables, linear regression equations were also developed considering volume as the dependent variable and $\mathrm{DBH}$ as the independent variable using linear model $\left[V=f\left(d^{2}\right)\right]$. Tables 5-8 give the species and diameter class-wise volume and biomass equations.

The wood specific gravity is an essential component for biomass and carbon stock estimation using volume equations. The wood specific gravity of tree species is available in the Global Wood Density Database compiled by Zanne et $a l^{28}{ }^{28}$, based on research work carried out across the globe. Table 9 gives the wood density/specific gravity of the selected tree species ${ }^{29,30}$, which is useful for the estimation of stem volume followed by tree biomass.

Tree volume and biomass estimates are essential for sustainable management and utilization of forest resources as well as carbon cycle dynamics in the ecosystem. In addition, UNFCCC has recognized the importance of forest carbon sink and the need of its preservation and 


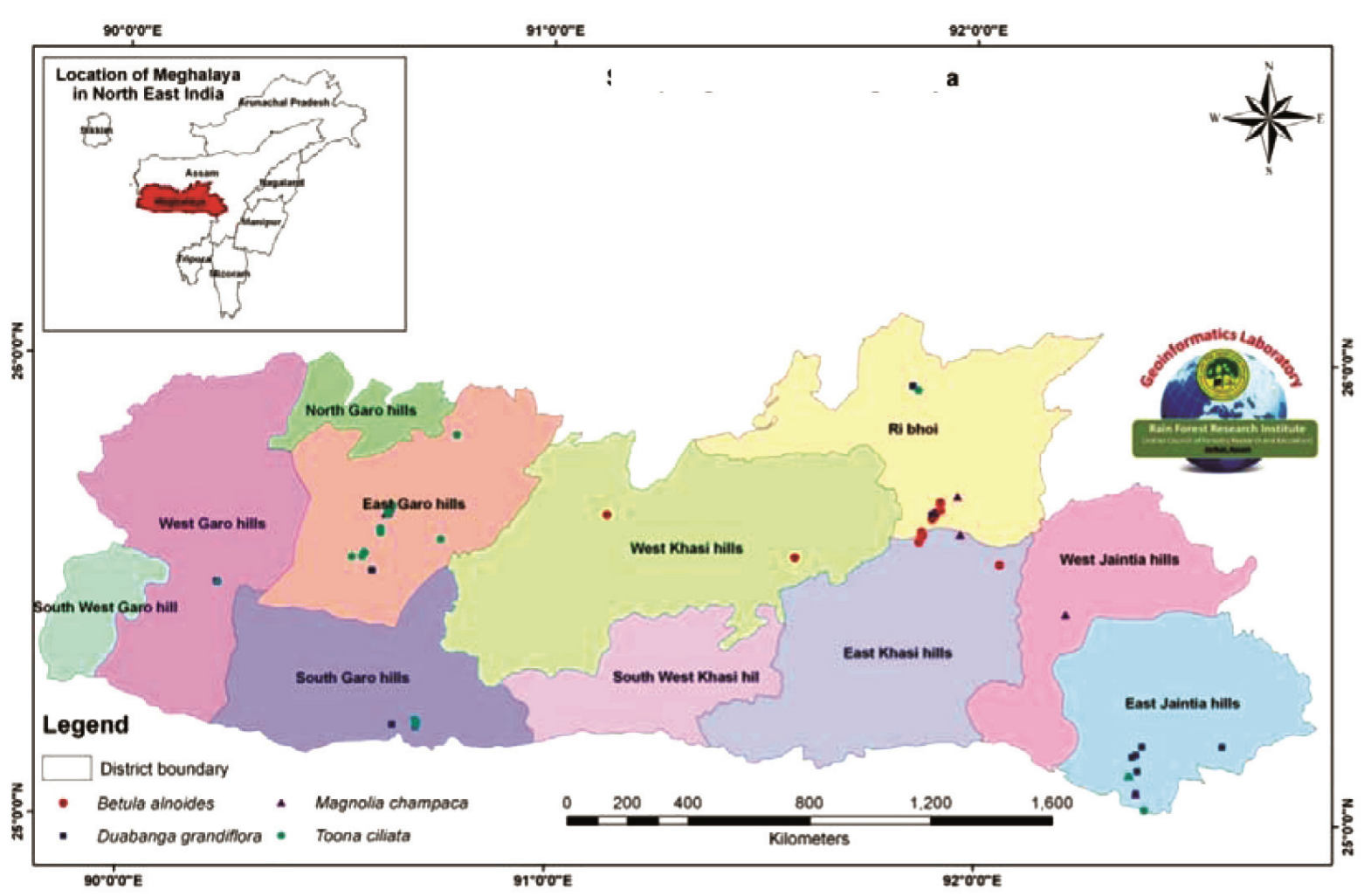

Figure 1. Species-wise sampling points in Meghalaya, India.

Table 1. Volume and biomass equations for Betula alnoides

\begin{tabular}{llll}
\hline Model for volume & Adj. $R^{2}$ & $\mathrm{SE}$ & $F(P$-value $)$ \\
\hline $\begin{array}{l}\text { Diameter class } 10-30 \mathrm{~cm} \\
V=0.365 * d^{2} * h\end{array}$ & 0.93 & 0.11 & $296.61(0.00)$ \\
$\begin{array}{l}\text { Diameter class } 31-50 \mathrm{~cm} \\
V=0.289 * d^{2} * h\end{array}$ & 0.92 & 0.30 & $260.80(0.00)$ \\
$\begin{array}{l}\text { Diameter class }>50 \mathrm{~cm} \\
V=0.255^{2} d^{2} h\end{array}$ & 0.92 & 0.67 & $217.09(0.00)$ \\
$\begin{array}{l}\text { Biomass }=\text { Stem volume } \times \text { wood } \\
\text { volume } \times 0.573 .\end{array}$ & specific & gravity. & Biomass $=$ Stem \\
\hline
\end{tabular}

$n=75,25$ trees for each diameter class, adj. $R^{2}$ coefficient of determination and SE is standard error in Tables 1-8. Volume models based on $\mathrm{DBH}$ and height.

Table 2. Volume and biomass equations for Duabanga grandiflora

\begin{tabular}{llll}
\hline Model for volume & Adj. $R^{2}$ & $\mathrm{SE}$ & $F(P$-value $)$ \\
\hline $\begin{array}{l}\text { Diameter class } 10-30 \mathrm{~cm} \\
V=0.320 * d^{2} * h\end{array}$ & 0.95 & 0.08 & $438.72(0.00)$ \\
$\begin{array}{l}\text { Diameter class } 31-50 \mathrm{~cm} \\
V=0.328 * d^{2} * h\end{array}$ & 0.91 & 0.41 & $249.89(0.00)$ \\
$\begin{array}{l}\text { Diameter class }>50 \mathrm{~cm} \\
V=0.286 * d^{2} * h\end{array}$ & 0.91 & 1.12 & $234.52(0.00)$ \\
$\begin{array}{l}\text { Biomass }=\text { Stem volume } \times \text { wood } \\
\text { volume } \times 0.382 .\end{array}$ & specific & gravity. & Biomass $=$ Stem \\
\hline
\end{tabular}

Volume models based on DBH and height. enhancement to combat global climate change through carbon sequestration. Terrestrial carbon stocks and changes are difficult to assess ${ }^{31}$ and most estimates are subject to uncertainty ${ }^{32,33}$. Among the available methods, destructive sampling is a direct way of biomass and carbon stock estimation which involves felling of trees and measuring their components such as trunk, leaves and branches to obtain dry weight ${ }^{34}$. Rai and Proctor ${ }^{35}$ developed regression equations to relate biomass and DBH using harvesting of trees in the Western Ghats and estimated aboveground tree biomass. The study revealed that the bole and branch biomass was within $95 \%$ confidence limit of the total above-ground biomass. Also, allometric equations for Pinus kesiya in Meghalaya were developed using harvest method. It was found that $\log (Y)=a+b \log D+$ $c(\log D)^{2}+d(\log D)^{3}$ was the best fit for biomass estimation of tree and its various components ${ }^{16}$.

Non-destructive sampling of desired variables is another method of biomass estimation, which is most appropriate for rare or protected tree species where harvesting of such species is not feasible ${ }^{36}$. Volume equations developed using non-destructive measurements of standing trees require wood specific gravity to transform stem volume into biomass and carbon stock. Generally volume equations are developed using DBH and tree height as independent variables. The regression models using DBH and tree height can estimate stem volume. This stem volume can be converted into biomass using wood specific gravity 
of the particular tree species. In the present study we have developed species-specific volume equations for $B$. alnoides, D. grandiflora, $M$. champaca and T. ciliata found in Meghalaya. A completely non-destructive approach was used for data collection in standing trees by means of various scientific equipment. The experimental results revealed that tree stem volume had strong linear relationship with DBH and height $\left(R^{2}>0.900\right)$. In 1977, Sharma and Jain $^{37}$ prepared regional volume tables for $D$. grandiflora in Manipur, NE India without the felling of trees. A linear regression model $V=a+b D^{2} H$ was developed with correlation coefficient $(R=0.993)$. The regression equation obtained from the data was $V=0.081671+$ $0.319025 D^{2} H$. Based on this regression model, a regional

Table 3. Volume and biomass equations for Magnolia champaca

\begin{tabular}{llll}
\hline Model for volume & Adj. $R^{2}$ & SE & $F(P$-value $)$ \\
\hline $\begin{array}{l}\text { Diameter class } 10-30 \mathrm{~cm} \\
\quad V=0.372 * d^{2} * h\end{array}$ & 0.93 & 0.11 & $491.69(0.00)$ \\
$\begin{array}{l}\text { Diameter class } 31-50 \mathrm{~cm} \\
V=0.272 * d^{2} * h\end{array}$ & 0.92 & 0.25 & $410.06(0.00)$ \\
$\begin{array}{l}\text { Diameter class }>50 \mathrm{~cm} \\
V=0.265 * d^{2} * h\end{array}$ & 0.98 & 0.37 & $407.46(0.00)$ \\
$\begin{array}{l}\text { Biomass }=\text { Stem volume } \times \text { wood } \\
\text { volume } \times 0.670 .\end{array}$ & specific & gravity. & Biomass $=$ Stem \\
\hline
\end{tabular}

Volume models based on DBH and height.

Table 4. Volume and biomass equations for Toona ciliata

\begin{tabular}{llll}
\hline Model for volume & Adj. $R^{2}$ & SE & $F(P$-value $)$ \\
\hline $\begin{array}{l}\text { Diameter class } 10-30 \mathrm{~cm} \\
V=0.298 * d^{2} * h\end{array}$ & 0.88 & 0.11 & $171.55(0.00)$ \\
$\begin{array}{l}\text { Diameter class } 31-50 \mathrm{~cm} \\
V=0.186^{*} d^{2} * h\end{array}$ & 0.93 & 0.21 & $297.57(0.00)$ \\
$\begin{array}{l}\text { Diameter class }>50 \mathrm{~cm} \\
V=0.253 * d^{2} * h\end{array}$ & 0.94 & 0.82 & $288.29(0.00)$ \\
$\begin{array}{l}\text { Biomass }=\text { Stem volume } \times \text { wood } \\
\text { volume } \times 0.560 .\end{array}$ & specific & gravity. & Biomass $=$ Stem \\
\hline
\end{tabular}

Volume models based on DBH and height.

Table 5. Volume and biomass equations for B. alnoides

\begin{tabular}{llll}
\hline Model for volume & Adj. $R^{2}$ & SE & $F(P$-value $)$ \\
\hline $\begin{array}{l}\text { Diameter class } 10-30 \mathrm{~cm} \\
\quad V=6.814 * d^{2}\end{array}$ & 0.92 & 0.12 & $244.07(0.00)$ \\
$\begin{array}{l}\text { Diameter class } 31-50 \mathrm{~cm} \\
\quad V=6.272 * d^{2}\end{array}$ & 0.92 & 0.30 & $260.77(0.00)$ \\
$\begin{array}{l}\text { Diameter class }>50 \mathrm{~cm} \\
V=6.086 * d^{2}\end{array}$ & 0.87 & 0.83 & $135.82(0.00)$ \\
$\begin{array}{l}\text { Biomass }=\text { Stem volume } \times \text { wood } \\
\text { volume } \times 0.573 .\end{array}$ & specific & gravity. & Biomass $=$ Stem \\
\hline
\end{tabular}

Volume models based on DBH. volume table of $D$. grandiflora was prepared for Manipur. Since 1977, the present study is the second attempt to develop regression models for important timber species of Meghalaya without the felling of trees. Montes et al. ${ }^{38} \mathrm{de}-$ veloped a non-destructive method for biomass estimation of Juniperus thurifera woodlands in the High Central Atlas, south of Morocco, where tree biomass was estimated using two photographs at orthogonal angles and samples of branches, leaves as well as dendrometric measurements. Climbing the tree is another non-destructive method of measurement of various parts ${ }^{39}$ or simply measuring $\mathrm{DBH}$, height of the tree, volume of the tree and wood density ${ }^{40}$ and calculating the biomass using allometric equations. The present study utilized Mantax

Table 6. Volume and biomass equations for D. grandiflora

\begin{tabular}{llcc}
\hline Model for volume & Adj. $R^{2}$ & SE & $F(P$-value $)$ \\
\hline $\begin{array}{l}\text { Diameter class } 10-30 \mathrm{~cm} \\
V=4.926^{*} d^{2}\end{array}$ & 0.91 & 0.11 & $239.72(0.00)$ \\
$\begin{array}{l}\text { Diameter class } 31-50 \mathrm{~cm} \\
V=7.177 * d^{2}\end{array}$ & 0.91 & 0.39 & $266.15(0.00)$ \\
$\begin{array}{l}\text { Diameter class }>50 \mathrm{~cm} \\
V=7.889 * d^{2}\end{array}$ & 0.92 & 1.03 & $285.52(0.00)$ \\
$\begin{array}{l}\text { Biomass }=\text { Stem volume } \times \text { wood } \\
\text { volume } \times 0.382 .\end{array}$ & specific & gravity. & Biomass $=$ Stem \\
\hline
\end{tabular}

Volume models based on DBH.

Table 7. Volume and biomass equations for M. champaca

\begin{tabular}{lccc}
\hline Model for volume & Adj. $R^{2}$ & SE & $F$ (P-value) \\
\hline $\begin{array}{l}\text { Diameter class } 10-30 \mathrm{~cm} \\
\quad V=6.120 * d^{2}\end{array}$ & 0.92 & 0.11 & $429.85(0.00)$ \\
$\begin{array}{l}\text { Diameter class } 31-50 \mathrm{~cm} \\
\quad V=5.727 * d^{2}\end{array}$ & 0.86 & 0.34 & $218.30(0.00)$ \\
$\begin{array}{l}\text { Diameter class }>50 \mathrm{~cm} \\
V=6.535 * d^{2}\end{array}$ & 0.99 & 0.31 & $582.37(0.00)$
\end{tabular}

Biomass $=$ Stem volume $\times$ wood specific gravity. Biomass $=$ Stem volume $\times 0.670$.

Volume models based on DBH.

Table 8. Volume and biomass equations for T. ciliata

\begin{tabular}{lccc}
\hline Model for volume & Adj. $R^{2}$ & SE & $F(P$-value $)$ \\
\hline $\begin{array}{l}\text { Diameter class } 10-30 \mathrm{~cm} \\
\quad V=4.897 * d^{2}\end{array}$ & 0.81 & 0.13 & $105.74(0.00)$ \\
$\begin{array}{l}\text { Diameter class } 31-50 \mathrm{~cm} \\
\quad V=4.253 * d^{2}\end{array}$ & 0.91 & 0.24 & $211.96(0.00)$ \\
$\begin{array}{l}\text { Diameter class }>50 \mathrm{~cm} \\
\quad V=6.591 * d^{2}\end{array}$ & 0.95 & 0.74 & $352.87(0.00)$
\end{tabular}

Biomass $=$ Stem volume $\times$ wood specific gravity. Biomass $=$ Stem volume $\times 0.560$.

Volume models based on DBH. 
RESEARCH ARTICLES

Table 9. Wood specific gravity of selected tree species

\begin{tabular}{lcc}
\hline Species & Wood specific gravity $\left(\mathrm{g} / \mathrm{cm}^{3}\right)$ & Reference \\
\hline Betula alnoides & 0.573 & 29 \\
Duabanga grandiflora & 0.382 & 29 \\
Magnolia champaca & 0.670 & 30 \\
Toona ciliata & 0.560 & 30 \\
\hline
\end{tabular}

Source: Zanne et $_{\text {al. }}{ }^{28}$.

Black Calliper with Gator Eyes for measurement of frustum diameter from a distance and Nikon Rangefinder to measure the length of frustum as well as total tree height. Such types of equipment/approaches avoid physical measurements in standing trees by climbing, which is a time-consuming and labour-intensive method for nondestructive measurement of tree volume and biomass.

\section{Conclusion}

Development of species-specific volume equations or regression models is essential to achieve higher levels of precision in above-ground biomass and carbon stock estimation of a forest ecosystem. Apart from this, estimation of net merchantable timber of a forest area is essential for extraction of timber. These operations require species-specific volume equations or allometric models for precise estimation. Development of volume and biomass equations requires felling of sufficient number of trees in different diameter classes, which is timeconsuming and expensive. In the present study, we have developed regression models for selected tree species of Meghalaya using modern scientific equipment. This is a rapid process which avoids felling of trees and also minimizes the cost. The study concludes that speciesspecific local and regional volume equations can be developed within a short time span without destruction of trees and at a lower cost. Similar work in other parts of NE India for development of species-specific volume/ biomass equations for important timber species is essential to achieve accuracy in volume and biomass estimation as well as carbon stock estimation and greenhouse gas inventory data preparation in the country.

1. Pandey, R., Dhall, S. P., Kanwar, B. S. and Bhardwaj, S. D., Some models for predicting volume of Populus deltoids. Indian For., 1998, 124(8), 629-632.

2. Stiellfor, W. M., Rapid estimation of volume in red pine plantation. For. Chron., 1957, 33(4), 334-340.

3. Woessner, R. A., Stem volume equation in young cottonwood clones - which equation? In Proceedings 12th SFTIC, 1973, pp. 270-275.

4. Harding, R. B. and Griger, D. G., Individual tree biomass estimation equations for plantation grown white spruce in northern Minnesota. Can. J. For. Res., 1985, 15(5), 738-739.
5. Yamamoto, K., A simple volume estimation system and its application to three coniferous species. Can. J. For. Res., 1994, 24, 1289-1294.

6. Tewari, V. P. and Gadow, K. V., Modelling the relationship between tree diameters and heights using $S_{\mathrm{BB}}$ distribution. For. Ecol. Manage., 1999, 119, 171-176.

7. Phillips, O. L. et al., Changes in biomass of tropical forests: evaluating potential biases. Ecol. Appl., 2002, 12, 576-587.

8. Dudley, N. S. and Fownes, J. H., Preliminary biomass equations for eight species of fast-growing tropical trees. J. Trop. For. Sci., 1991, 5(1), 68-73.

9. Brown, S., Estimating biomass and biomass change of tropical forests: a primer. FAO Forestry Paper 134, FAO Rome, 1997, p. 55.

10. Brown, S., Gillespie, A. and Lugo, A., Biomass estimation methods for tropical forests with applications to forest inventory data. For. Sci., 1989, 35, 881-902.

11. Chambers, J. Q., Dos Santos, J., Ribeiro, R. J. and Higuchi, N., Tree damage, allometric relationships, and aboveground net primary production in central Amazon forest. For. Ecol. Manage., 2001, 152, 73-84.

12. Schmidt, A., Poulain, M., Klein, D., Krause, K., Pena-Rojas, K., Schmidt, H. and Schulte, A., Allometric above-belowground biomass equations for Nothofagus pumilio (Poepp. \& Endl.) Natural regeneration in the Chilean Patagonia. Ann. For. Sci., 2009, 66, 513-518.

13. Li, R. and Weiskittel, A. R., Comparison of model forms for estimating stem taper and volume in the primary conifer species of the North American Acadian region. Ann. For. Sci., 2010, 67, 302-316.

14. Schroeder, P., Brown, S., Mo, J., Birdsey, R. and Cieszewski, C., Biomass estimation for temperate broadleaf forests of the United States using inventory data. For. Sci., 1997, 43, 424-434.

15. Ravindranath, N. H., Somashekhar, B. S. and Gadgil, M., Carbon flow in Indian forests. Climate Change, 1997, 35, 297-320.

16. Baishya, R. and Barik, S. K., Estimation of tree biomass, carbon pool and net primary production of an old-growth Pinus kesiya Royle ex. Gordon forest in north-eastern India. Ann. For. Sci., 2011, 68(4), 727-736.

17. UNFCCC, Report of the Conference of the Parties on its thirteenth session, held in Bali from 3 to 15 December 2007. Addendum, Part 2. Document FCCC/CP/2007/6/Add.1, United Nations Framework Convention on Climate Change, Bonn, Germany, 2008.

18. Basuki, T. M., Van Laake, P. E., Skidmore, A. K. and Hussin, Y. A., Allometric equations for estimating the above-ground biomass in tropical lowland Dipterocarp forests. For. Ecol. Manage., 2009, 257, 1684-1694.

19. Clark, D. A., Brown, S., Kicklighter, D. W., Chambers, J. Q. and $\mathrm{Ni}$, J., Measuring net primary production in forests: concepts and field methods. Ecol. Appl., 2001, 11(2), 356-370.

20. Wang, H., Hall, C. A. S., Scatena, F. N., Fetcher, N. and Wu, W., Modeling the spatial and temporal variability in climate and primary productivity across the Luquillo Mountains, Puerto Rico. For. Ecol. Manage., 2003, 179, 69-94.

21. Joshi, N. R. et al., Development of Allometric equations for Paulownia tomentosa to estimate biomass and carbon stocks: an assessment from ICIMOD Knowledge Park, Godavari, Nepal. ICIMOD Working Paper 2015/10, 2015, p. 38.

22. https://www.manualslib.com Nikon Manuals > Measuring Instruments (accessed on 5 June 2018).

23. www.haglofsweden.com (accessed on 5 June 2018).

24. Husch, B., Miller, C. I. and Beers, T. W., Forest Mensuration, The Roland Press Co., New York, USA, 1982, 3rd edn, p. 402.

25. Amin, T. M., Non destructive method for estimating log volume for Melia azedarach L. trees in Erbil-Iraqi Kurdistan region. ARO, Sci. J. Koya Univ., 2014, 2(2), 32-36; http://dx.doi.org/10.14500/ aro. 10027 . 
26. Goulding, C. J., Cubic spline curves and calculation of volume of sectionally measured trees. NZ J. For. Sci., 1997, 9(1), 89-99.

27. SPSS Base 16.0 User's Guide, SPSS Inc, Chicago, USA, 2007.

28. Zanne, A. E. et al., Global Wood Density Database, 2009; doi:http://dx.doi.org/10.5061/dryad.234/1.

29. Cheng, J. C., Yang, J. and Liu, P., Anatomy and Properties of Chinese Woods, Chinese Forestry Publishing, Beijing, China, 1992, p. 820.

30. Benthall, A. P., The Trees of Calcutta: and its Neighbourhood, Thacker Spink and Co Ltd, Calcutta, 1984.

31. IPCC, Report on good practice guidance for land use, land-use change and forestry. The Intergovernmental Panel on Climate Change, National Greenhouse Gas Inventories Programme; http://www.ipcc-nggip.iges.or.jp/public/gpglulucf/gpglulucf.htm

32. Lowe, H., Seufert, G. and Raes, F., Comparison of methods used within member states for estimating $\mathrm{CO}_{2}$ emissions and sinks to UNFCCC and UE monitoring mechanism: forest and other wooded land. Biotechnol. Agron. Soc. Environ., 2000, 4, 315-319.

33. Clark, D. A., Brown, S., Kicklighter, D. W., Chambers, J. Q., Thomlinson, J. R., Ni, J. and Holland, E. A., Net primary production in tropical forests: an evaluation and synthesis of existing field data. Ecol. Appl., 2001, 11(2), 371-384.

34. Zianis, D. and Mencuccini, M., Aboveground biomass relationship for beech (Fagus moesiaca Cz.) trees in Vermio Mountain, northern Greece, and generalized equations for Fagus spp. Ann. For. Sci., 2003, 60, 439-448.

35. Rai, S. N. and Proctor, J., Ecological studies on four rainforests in Karnataka, India I. Environment, structure, floristic and biomass. J. Ecol., 1986, 74, 439-454.

36. Gibbs, H. K., Brown, S., Niles, J. O. and Foley, J. A., Monitoring and estimating tropical forest carbon stocks: making REDD a reality. Environ. Res. Lett., 2007, 2, 1-13.
37. Sharma, R. P. and Jain, R. C., Regional volume tables for Duabanga grandiflora WALP. (based on the data of Manipur state). Indian For., 1977, 103(11), 731-732.

38. Montes, N., Gauquelin, T., Badri, W., Bertaudiere, V. and Zaoui, E. H., A non-destructive method for estimating above-ground forest biomass in threatened woodlands. For. Ecol. Manage., 2000, 130, 37-46.

39. Aboal, J. R., Arevalo, J. R. and Fernandez, A., Allometric relationships of different tree species and stand above ground biomass in the Gomera laurel forest (Canary Islands). Flora, 2005, 200, 264-274.

40. Ravindranath, N. H. and Ostwald, M. (eds), Methods for estimating above-ground biomass. In Carbon Inventory Methods: Handbook for Greenhouse Gas Inventory, Carbon Mitigation and Roundwood Production Projects, Springer Science + Business Media BV, 2008, p. 287.

ACKNOWLEDGEMENTS. We thank the Forest and Environment Department, Government of Meghalaya, Shillong for funding the research project and providing logistic support during field work and data collection. We also thank Dr D. J. Das, and Shri Abhijit Medhi (Geo-informatics Laboratory, Rain Forest Research Institute, Jorhat, Assam) for preparation of map, and Ms Azka Anwer for assistance in data analysis.

Received 3 April 2018; revised accepted 7 September 2018

doi: $10.18520 / \mathrm{cs} / \mathrm{v} 116 / \mathrm{i} 1 / 75-81$ 